\title{
Green Airlines 2025: Environment and Sustainability in Commercial Aviation - A Scenario Study
}

\author{
Felix Will ${ }^{1}$ and Gilbert Tay ${ }^{2}$ \\ Technical University of Munich, 85748 Garching, Germany \\ Axel Becker ${ }^{3}$ \\ Airbus, 21129 Hamburg, Germany \\ Daniel Carnelly ${ }^{4}$ and Frédéric Eychenne ${ }^{5}$ \\ Airbus, 31707 Blagnac Cedex, France \\ Mirko Hornung ${ }^{6}$ \\ Technical University of Munich, 85748 Garching, Germany
}

\begin{abstract}
Reducing the environmental impact is a great challenge for the aviation industry. However, the difficulty to anticipate future developments combined with long product lifecycles make strategy definition for aviation stakeholders challenging. This paper therefore presents a foresight project of a joint study by Airbus, Technical University of Munich, and Bauhaus Luftfahrt. The methodology uses a scenario approach to develop three alternative scenarios. They represent future situations of the aviation world in the year 2025 with focus on environmental topics. Driving factors of influence for the future development are identified, for instance, the world economy, environmental regulations, or the passenger's perception of aviation. Finally, strategic implications for airlines and aircraft manufacturers and possible fields of cooperation are discussed within the scenarios. Aircraft fleet renewals, for example, are considered as the most important step for airlines in all three scenarios. Sustainable fuels are not expected to have a significant contribution until 2025.
\end{abstract}

\section{Topic Motivation}

$\mathrm{T}^{\mathrm{H}}$ HE transport sector, in general, undoubtedly has a considerable impact on our environment. According to the Organisation for Economic Co-operation and Development (OECD), $\mathrm{CO}_{2}$ emissions caused by transport represent $23 \%$ of man-made $\mathrm{CO}_{2}$ emissions globally and $30 \%$ in OECD countries. ${ }^{1}$ Reducing transportation's negative impacts on the environment thus is a crucial goal, e.g. for political institutions and the transportation industry. Aviation, more specifically, is responsible for around $2 \%$ of the total man-made $\mathrm{CO}_{2}$ emissions worldwide. ${ }^{2} \mathrm{Apart}$ from $\mathrm{CO}_{2}$ emissions further topics are of relevance for the aviation industry such as other gaseous emissions or local air quality and noise emissions in the vicinity of airports.

These challenges are intensified by the comparatively high visibility of aviation in the public perception. Many airports face concerns and opposition to different degrees, e.g. by residents, due to the airport's environmental impact. In Europe, for instance, this is true for existing airports and for intended expansion projects in particular. Effective strategies are therefore required to enable sustainable growth for the aviation industry without negatively impacting today's quality of life or depleting the resources needed in the future. Consequently, efforts to minimize aviation's environmental impact play a major role in aircraft and engine design and manufacturing. Furthermore, aircraft operations are examined in order to reduce their environmental impact.

\footnotetext{
${ }^{1}$ Research Assistant, Institute of Aircraft Design, Boltzmannstrasse 15, AIAA Student Member.

${ }^{2}$ Research Assistant, Institute of Aircraft Design, Boltzmannstrasse 15.

${ }^{3}$ Manager Trend Research, Cabin Marketing, Kreetslag 10.

${ }^{4}$ Technical Marketing Director, Aircraft Performance \& Environment, Rond Point Maurice Bellonte 1.

${ }^{5}$ New Energies Programme Manager, Environmental Affairs, Rond Point Maurice Bellonte 1.

${ }^{6}$ Professor, Institute of Aircraft Design, Boltzmannstrasse 15, AIAA Senior Member.
} 
A number of strategies and goals have been defined to meet the challenges by the aviation industry. For instance, the Air Transportation Action Group (ATAG) agreed on quantified climate change targets, e.g. improving fleet fuel efficiency by an average of $1.5 \%$ per year until 2020. The industry also aims at reaching a peak in its net carbon emissions in 2020. By 2050, the industry intends to reduce its net carbon footprint to 50\% compared to $2005 .{ }^{3}$ In 2001 the Advisory Council for Aeronautical Research in Europe (ACARE) decided on a number of targets for 2020 compared with the year 2000. These goals include intended reductions in fuel consumption and $\mathrm{CO}_{2}$ emissions by $50 \%$ per passenger kilometer, of $\mathrm{NO}_{\mathrm{x}}$ emissions by $80 \%$, and of perceived noise by $50 \%{ }^{4}$

In order to reach these targets, the aviation industry has defined a four-pillar strategy as published by the International Air Transport Association (IATA). ${ }^{5}$ Firstly, the strategy includes technological improvements at the aircraft or through sustainable biofuels, secondly, efficient flight operations, thirdly, improved air traffic management and airport infrastructure, and lastly, economic instruments. The four-pillar approach makes obvious that the environmental challenges require actions by all stakeholders of the aviation industry, thus the quest for effective strategies is of interest for the entire industry.

\section{Scenario-Based Methodical Approach}

\section{A. Goals of the Study}

The essence of the study is to apply the scenario technique to environmental topics in commercial aviation according to the methodical approach detailed in this chapter, Section C. One goal of the project consequently is to create alternative and plausible "scenarios", thus possible future situations of the aviation world relevant to environmental topics, for the year 2025. One sub-goal in the process of creating the scenarios is to identify driving socio-economic, political, or technological factors that influence the development and the future situation of the aviation system.

From the alternative scenarios, one main goal of the study is to discuss implications the scenarios might have on airlines and aircraft original equipment manufacturers (OEM). Specifically, one of the goals is to analyze options with respect to the cooperation between airlines and aircraft OEMs concerning environmental topics. Besides these future orientated goals, one additional aim of the project is to design and apply a methodical approach for the evaluation of environmental activities of airlines.

\section{B. The Use of Scenario Planning in Strategic Foresight}

Scenario planning has found its increasingly popular use as a strategic planning tool in the last few decades to cope with uncertainty in the long-term strategic decision-making process. The analytical process used in the scenario planning process has an objective to yield unique insights in order to discover the various chances and risks that the future might bring. Van der Heijden even describes the creation of a unique insight as the ultimate success criteria of all strategy work. ${ }^{6}$ This section presents an overview of the fundamentals and the development of scenario planning in the last five decades, followed by a descriptive "navigational aid" in the classification of the methodology used in this foresight project. The latter is imperative in order to understand correctly this particular application of scenario planning in the midst of a multitude of techniques and methodologies used in the development of scenarios, which some authors refer to as a "methodological chaos". 8;7

The principle questions asked in a scenario study determines the classification of the scenario typology. These questions according to Börjeson et al. are 'What will happen?', 'What can happen?' and 'How can a specific target be reached?'. ${ }^{9}$ In this paper, the term "scenario" has an explorative nature and describes multiple consistent pictures of comprehensive, future situations and a description of how these situations have emerged. This answers the principle question "What might happen?" posed in this scenario study. Each scenario is to be treated as equally plausible, if not, the scenario study would not be effective when working with conditions that are not going to be taken seriously. The approach to scenario building depicted here used at the Institute of Aircraft Design of the Technical University of Munich (TUM) has been successfully applied in several foresight projects, see Kuhlmann et al., Phleps and Hornung, and Randt et al. for examples. ${ }^{10-12}$

This approach has been adapted from the work of Gausemeier et al., one of the early pioneering German literature having wide-ranging influences in the practical implementation of the explorative scenario methodology in business and industry. ${ }^{13}$ Gausemeier et al. broke down the scenario building process into five phases, namely the scenario preparation phase, which defines the "investigative object" of the scenario project and the time horizon of the project. Secondly, the scenario-environment analysis phase, which identifies the most important key factors of the scenarioenvironment relevant to the future. Thirdly, the scenario prognostics phase, which explores the various future

development possibilities of the identified key factors. Fourthly, the scenario generation phase which evaluates the 
compatibility of the alternative developments and compiles the possible future scenarios. Lastly, the scenario transfer phase, which is used to develop robust goals and strategies for the future.

\section{Scenario \& Project Approach}

\section{Time Frame and Participants of the Project}

The scenario study was carried out at the Technical University of Munich during the months April 2015 to July 2015 by a project team of 16 persons in total. The project was led by the authors of this paper, thus two researchers of Technical University of Munich and three Airbus professionals. One additional researcher of Bauhaus Luftfahrt and ten undergraduate and graduate students enrolled at Technical University of Munich completed the project team. The students, enrolled in courses in aerospace engineering, mechanical engineering, and engineering management, were working on the project during four months of their regular studies.

Organizationally, apart from a kick-off meeting and a public presentation of the final results, the backbone of the project consisted of three two-day workshops. ${ }^{14}$ Between the workshops, additional work was done by the project team. During the project, different sub-teams were created that comprised both students and at least one of the authors of the study.

\section{Scenario Approach Applied in the Study}

This scenario process is generally based on a six-step-approach as displayed in Table 1. In step 1, the topic to be examined, key questions to be addressed, and the considered time horizon are defined.

In step 2, driving factors that are considered of influence for the topic within the time horizon are identified. These driving factors, also called environment factors, are then evaluated in an uncertainty-impact-analysis according to the uncertainty of their future development, and according to their impact on the research topic. In that, the certainty of the future evolution of an environment factor is discussed and evaluated on a scale from 0 (uncertain) to 4 (certain). The impact, accordingly, is rated from 0 (low impact) to 4 (high impact). Ten environment factors with the highest uncertainty and impact were selected as key environment factors. Subsequently, all environment factors are defined in detail by formulating so-called written factor essays which include the following information: Firstly, the factor's title, secondly, a precise definition of the factor, and thirdly, its status quo (year 2015) which is derived from literature research undertaken. Additionally, future projections, thus possible future states of an environment factor, are discussed and defined for the year 2025. The amount of future projections depends on the uncertainty of the corresponding environment factor, reaching from one projection up to three or four projections. Future projections and additional explanations to each projection are included in the factor essays, as well.

In step 3, a consistency analysis evaluates each pair of all future projections of the key environment factors according to their consistency. If two projections of two environment factors are evaluated as completely consistent, the score 5 is given, if two projections were evaluated as completely inconsistent, the score 1 is given; consistency values 4 and 2 are used accordingly. If two projections are evaluated neither consistent nor inconsistent, thus neutral, or if the two corresponding environment factors are regarded as independent, the score 3 is given.

\begin{tabular}{|l|l|l|}
\hline No & Step & Goal \\
\hline 1 & Problem Definition & Define research topic, key questions and considered time horizon \\
\hline 2 & $\begin{array}{l}\text { Analysis of the Scenario } \\
\text { Environment }\end{array}$ & $\begin{array}{l}\text { Identify driving factors (environment factors) } \\
\text { Evaluate uncertainty and impact of environment factors (U-I-analysis) } \\
\text { Precisely define environment factors \& their status quo } \\
\text { Define possible future states (projections) of environment factors }\end{array}$ \\
\hline 3 & Consistency Analysis & $\begin{array}{l}\text { Evaluate consistency for every pair of all future projections of the key } \\
\text { environment factors }\end{array}$ \\
\hline 4 & Raw Scenarios & $\begin{array}{l}\text { Create raw scenarios by combination of one future projection per } \\
\text { environment factor }\end{array}$ \\
\hline 5 & Scenario Storyboards & $\begin{array}{l}\text { Create scenario storyboards by formulating written descriptions of the } \\
\text { raw scenarios }\end{array}$ \\
\hline 6 & Implication Analysis & $\begin{array}{l}\text { Analyze implications for selected stakeholders considering all } \\
\text { alternative scenarios }\end{array}$ \\
\hline
\end{tabular}

Table 1. Six-step-approach to create the scenarios

In step 4, scenarios are generated that describe future situations of the aviation world within the considered time horizon. The scenarios are generated from the consistency values of all key environment factors evaluated in step 3 using the scenario tool RAHS (Risk Assessment and Horizon Scanning) developed by the German Federal Armed 
Forces. ${ }^{15}$ Supported by the RAHS tool, three scenarios are selected that show a) high internal consistency within a scenario as well as b) high diversity between the scenarios in order to cover a wide range of possible future developments. Future projections of the additional environment factors are selected according to discussions of their plausibility within the three scenarios. The result of step 4 are three so-called raw scenarios, where one raw scenario is a combination of one future projection per environment factor throughout all factors.

In step 5, scenario storyboards are created which are written descriptions of the raw scenarios in order to foster a better understanding of the scenarios, both for the scenario team and for subsequent users of the scenarios. The storyboards also serve to emphasize causal connections, thus reason and consequences, between environment factors.

In step 6, implications for aviation stakeholders are analyzed that each of the alternative scenario would bring for a particular stakeholder. From this, robust strategies for stakeholders can be developed that aim at being able to cope with varying future developments. In this study, implications are firstly examined for airlines. Secondly, implications for an aircraft OEM and possible cooperation with airlines concerning environmental topics are analyzed.

\section{Airline Evaluation Regarding Environment and Sustainability}

Within this study a method of evaluating an airline concerning environmental topics was designed and applied. The airline evaluation generally rates an airline within the two following areas. Firstly, on "strategy \& communication", which attempts to evaluate strategical aspects of an airline, and secondly, on "operational implementation" which aims at evaluating environmentally relevant operational activities of an airline. Both areas consist of seven criteria as detailed in Table 2 and Table 3 . For each criteria an airline is evaluated by a score from 0 (not performing at all) to 5 (fully performing). By weighing the different criteria according to the third column of Table 2 and Table 3, an overall score is calculated both for the area "strategy \& communication" and for the area "operational implementation".

The airline evaluation is applied to a number of selected, real airlines. To further airlines the method could later be applied as well. In order to be able to evaluate the airlines, significant literature research is undertaken for each airline considering mostly online sources published by the airlines themselves or by third parties.

In this scenario study, the airline evaluation is applied during two different steps. Firstly, the airlines are rated during step 2 (see Table 1) evaluating their situation in the status quo (year 2015). In Table 2 and Table 3, the listed weights represent the assumed relevance of the criteria for the status quo. Secondly, the airline evaluation is applied during step 6 (see Table 1) in order to analyze their possible future situation within the three scenarios. For this, criteria weights are derived for all three scenarios based on the scenarios created in step 4 and step 5 (see Table 1). The scenario-specific criteria weights are introduced along with the scenarios in Chapter III.

\begin{tabular}{|l|l|r|l|}
\hline Area & Criteria & Weight & Explanation \\
\hline \multirow{3}{*}{} & $\begin{array}{l}\text { Corporate Social } \\
\text { Responsibility }\end{array}$ & $15 \%$ & $\begin{array}{l}\text { Rating of an airline's activities with respect to corporate social responsibility } \\
\text { (CSR) related reporting and community involvement. }\end{array}$ \\
\cline { 2 - 4 } & $\begin{array}{l}\text { Corporate } \\
\text { Environmental } \\
\text { Targets }\end{array}$ & $30 \%$ & $\begin{array}{l}\text { Definition, breakdown and evaluation of corporate targets with respect to } \\
\text { environmental performance. }\end{array}$ \\
\cline { 2 - 4 } & $\begin{array}{l}\text { Cooperation and } \\
\text { Alliances }\end{array}$ & $15 \%$ & $\begin{array}{l}\text { Assessment of the degree to which an airline sets up and joins cooperation } \\
\text { within the industry, the research, governments or NGOs. }\end{array}$ \\
\cline { 2 - 4 } & Communication & $15 \%$ & $\begin{array}{l}\text { Extent to which an airline communicates its environmental efforts towards } \\
\text { the general public and the passenger. }\end{array}$ \\
\cline { 2 - 4 } & Carbon Offset & $10 \%$ & $\begin{array}{l}\text { Rating of the airline's carbon offset offering and respective passenger } \\
\text { adoption rates. }\end{array}$ \\
\cline { 2 - 4 } & Sustainable Services & $5 \%$ & $\begin{array}{l}\text { Rating of the airline's promotion of sustainable services such as sustainable } \\
\text { tourism or offering utensils coming from sustainable sources. }\end{array}$ \\
\cline { 2 - 4 } & $\begin{array}{l}\text { Environmental } \\
\text { Process }\end{array}$ & $10 \%$ & $\begin{array}{l}\text { Evaluation of the airline's commitment to the environmental challenges, e.g. } \\
\text { by reviewing the existence of an environmental department. }\end{array}$ \\
\hline
\end{tabular}

Table 2. Airline evaluation criteria in the area "strategy $\&$ communication" including weights of the status quo (year 2015) 


\begin{tabular}{|l|l|r|l|}
\hline Area & Criteria & Weight & Explanation \\
\hline \multirow{3}{*}{} & Aircraft Fleet & $30 \%$ & $\begin{array}{l}\text { Assessment of the airline's average fleet age and their orders of new aircraft } \\
\text { types. }\end{array}$ \\
\cline { 2 - 4 } & Alternative Fuels & $15 \%$ & Rating of the airline's involvement in biofuel research and operational testing. \\
\cline { 2 - 4 } & $\begin{array}{l}\text { Flight Operations \& } \\
\text { ATM initiatives }\end{array}$ & $25 \%$ & $\begin{array}{l}\text { Evaluation of the airline's flight operation activities, e.g. aircraft engine and } \\
\text { fuel monitoring, and the airline's efforts regarding air traffic management } \\
\text { (ATM), e.g. initiatives such as optimization of climb and descent trajectories. }\end{array}$ \\
\cline { 2 - 4 } & $\begin{array}{l}\text { Ground Operations } \\
\text { \& Ground } \\
\text { Infrastructure }\end{array}$ & $15 \%$ & $\begin{array}{l}\text { Evaluation of the airline's ground operation activities, e.g. use of reverse thrust } \\
\text { on landing, taxiing with engines shut or reduced thrust for take-offs and climbs. }\end{array}$ \\
\cline { 2 - 4 } & $\begin{array}{l}\text { Maintenance } \\
\text { Practices }\end{array}$ & $5 \%$ & $\begin{array}{l}\text { Rating of the airline's efforts regarding aircraft/engine maintenance as well as } \\
\text { instrument accuracy verification. }\end{array}$ \\
\cline { 2 - 4 } & $\begin{array}{l}\text { In-flight Waste \& } \\
\text { Recycling }\end{array}$ & $5 \%$ & $\begin{array}{l}\text { Investigation of the airline's efforts regarding in-flight services processes, on } \\
\text { board waste and recycling management. }\end{array}$ \\
\cline { 2 - 4 } & Other Initiatives & $5 \%$ & $\begin{array}{l}\text { Rating of the airline's efforts regarding other initiatives, e.g. aircraft freight and } \\
\text { cargo capacity optimization. }\end{array}$ \\
\hline
\end{tabular}

Table 3. Airline evaluation criteria in the area "operational implementation" including weights of the status quo (year 2015)

\section{Results: Three Alternative Scenarios}

\section{A. Identified Environment Factors}

A major step in understanding a scenario study, as described in Chapter II, is identifying and examining environment factors that drive the future development of the research topic (see Table 1). Table 4 shows 12 selected environment factors out of a total of 20 factors identified and used in the study. Note that some environmental factors can be quantified, others cannot. The factors are classified in the areas "economics", "society", "politics", and "technology".

\begin{tabular}{|l|l|l|}
\hline Area & Title & Description \\
\hline Society & Acceptance/Perception of Aviation & General public opinion about aviation, its benefits and damages. \\
\hline Economics & Air Traffic Demand & $\begin{array}{l}\text { Air traffic demand measured in revenue passenger/tonne } \\
\text { kilometers (RPK/RTK) per year. }\end{array}$ \\
\hline Technology & Aircraft Production Capabilities & $\begin{array}{l}\text { Output of an OEM's aircraft final assembly lines in number of } \\
\text { aircraft per year. }\end{array}$ \\
\hline Economics & Airline Economic Situation & Mean net profit of global commercial airlines. \\
\hline Technology & Airport Airside Capacity & $\begin{array}{l}\text { Airport capacity, mostly restricted by runway system, in } \\
\text { movements per hour. }\end{array}$ \\
\hline Society & $\begin{array}{l}\text { Environmental Awareness \& } \\
\text { Sustainable Behavior }\end{array}$ & $\begin{array}{l}\text { Level of awareness of human influence on the environment and } \\
\text { level of actively behaving environmentally friendly. }\end{array}$ \\
\hline Politics & Environmental Regulations & $\begin{array}{l}\text { Intensity of environmental regulations on the aviation industry: } \\
\text { Globally concerning gaseous emissions, locally concerning local } \\
\text { air pollution or noise. }\end{array}$ \\
\hline Economics & Global Oil Price & $\begin{array}{l}\text { Average global oil price, only considering oil from fossil oil } \\
\text { resources, measured in USD/barrel. }\end{array}$ \\
\hline Society & Influence of Media on Aviation & $\begin{array}{l}\text { Influence of media on the public perception of aviation and on } \\
\text { decisions of the aviation industry. }\end{array}$ \\
\hline Technology & $\begin{array}{l}\text { Liberalization of Airspace (ATM, } \\
\text { ATC) }\end{array}$ & $\begin{array}{l}\text { Level of freedom an airline has w.r.t. flight routes, flight levels, } \\
\text { departure or arrival routes, and profiles. }\end{array}$ \\
\hline Society & PAX Travel Flexibility \& Demands & $\begin{array}{l}\text { Demands of passengers and level of flexibility concerning travel } \\
\text { time, comfort, and costs. }\end{array}$ \\
\hline Economics & $\begin{array}{l}\text { World Gross Domestic Product } \\
\text { Growth }\end{array}$ & \begin{tabular}{l} 
Growth of world gross domestic product (GDP) in \% per year. \\
\hline
\end{tabular}
\end{tabular}

Table 4. Selected environment factors and their definitions as identified and used in the study

\section{B. Scenario Storyboards}

The following section presents the three scenario storyboards created from their corresponding raw scenarios according to the methodology described in Chapter II. The storyboards are written from the point of view in the year 2025. 


\section{Scenario A: "Hand in Hand - Towards Prudent Sustainable Growth"}

Within the last ten years, major political crises could be avoided and solved. Stable political development encouraged global trading and innovations like "industry 4.0" pushed world GDP growth beyond forecasts (>3.5\%). Despite rising oil demand, improvements in technologies like fracking as well as the discovery of new oil and gas fields led to a decrease in oil price down to 55 USD per barrel today. As a consequence, the share of alternative fuels in aviation stayed on a commercial level of under $2 \%$.

Strong GDP growth allows people to travel more, for business as well as for leisure. As a consequence, air traffic demand increased on average by $\approx 5 \%$ p.a. To handle the higher air traffic demand, air space liberalization was regionally achieved. Projects like Single European Sky and NextGen proved to be successful, but at the same time alternative flight operations like continuous descent approach (CDA) could not be realized on a global level.

Better trading relations between nations favored worldwide more harmonized environmental regulations. In 2018, the "Dakar protocol" was passed. Key statement for aviation is a step by step reduction of $\mathrm{CO}_{2}$ emissions. Additionally, the protocol includes regulations regarding noise at noise polluted areas.

Retrofit solutions were integral for the fulfillment of the initial resolution step of the "Dakar protocol". Additionally, electric taxiing was implemented at major hubs to further reduce $\mathrm{CO}_{2}$ and noise emissions. As a second step a large number of modern aircraft was needed. Aircraft certificates were introduced as mandatory standards by the ICAO. Therefore the OEMs pushed the aircraft final assembly line output capabilities to better their book to bill ratio.

The need for more air travel and the implementation of environmental regulations led to an increase in the acceptance of aviation, despite the fact that the general environmental awareness of the public remained on a moderate level. The influence of media on aviation was limited, as aviation is no longer seen as a major environmental polluter. The media awareness on environment topics shifted to other industries.

The global airline economic situation is rather stable with regional improvements. Due to a fast growing middle class in Asia, revenues in this region increased. Because of the increased traffic demand focus on higher revenues was possible. To strengthen the market on a long term basis in Asia and Middle East, political economic support for aviation was increased furthermore, while the governmental support in the other markets remained at a constant level. The asymmetrically growing and ageing population happened as forecasted. Today 8 billion people are living on the earth. World middle class combined with the upper class make up of more than $1 / 3$ of the world population being potential customers for flying. Still a wide range of different passenger types need to be considered as the passenger travel flexibility and demands have barely changed.

The aviation industry did not suffer from significant cannibalization from other alternative means of transport. Planned airport expansion projects were mostly realized and no major set-backs occurred on a global scale. In order to facilitate passenger and goods transportation to the airports, significant operational and minor structural improvements needed to be made. Nevertheless, regional inconsistencies existed due to high urbanization. Emerging fields of technology together with a higher aircraft demand led to a decrease in the availability of non-fuel resources. To compensate for this, a slight increase in recycling old aircraft was observed.

\section{Scenario B: "Business as Usual?"}

Europe has seen resuming tensions between Russia and the Western countries due to the Ukraine crisis in the early 2010s. Defense spending on both sides remains on an elevated level. A rather fragmented international community, experiencing other conflicts as well, was not able to initiate common approaches.

Despite diplomatic crises, the world economy stabilized, resulting in a moderate world GDP growth $(\approx 3 \%)$. Asian economies grew slower than in boom years in the early 2000s, though Latin American and African markets gained more financial importance. Western Europe had to wrestle with financial problems after a close 'Grexit'. North America's importance on the global market decreased, but was generally able to maintain its level of prosperity.

Tougher ecological regulations and air space liberalizations for air transportation have been introduced regionally, e.g. in Western Europe or North America. Renewable energies cannot reach a global breakthrough due to comparatively high costs. However, countries in Northern Europe still make large efforts to achieve the goal of carbon neutral energy supply.

Continued fracking efforts in North America and a lack of unity for common production rates within the OPEC nations led to a global market price for oil at a relatively stable level around 70 USD per barrel. Due to stable oil prices, alternative aviation fuel development and extensive retro-fit upgrade programs continued with only moderate efforts. No commercial breakthrough for alternative fuels was achieved. Efficiency improvements stay in the focus, however, as fuel costs still make up between one third up to a half of an airline's fix costs.

Continued governmental support for Middle Eastern and Asian Pacific flag carriers led to a partly distorted market situation. Expectable cost development and moderate, but solid air traffic demand growth led to stable net profits and 
planning certainty for airlines. Many legacy carriers, as well as some 'grown-up' low-cost carriers tried to establish both low-cost und full-service carrier business models or expanded their network to medium and long haul flights.

The acceptance and perception of aviation stayed generally positive, despite a number of tragic incidents and local protest against noise pollution. This is credited to the undisputed high safety standards and rising efforts for environmental issues. Since the carbon neutral air traffic growth failed in 2020, the IATA revisited its targets and started negotiations with ICAO and OEMs.

Environmental awareness gained significance in Europe and in North America and found further ways into legislation, e.g. 'no-emission-zones' in cities, or strict noise and pollution limits around airports. Yet, the global political situation generally directed away attention from ecological topics. Environmental movements in China and India are currently emerging due to worsening situations in cities like New Delhi and Peking, though political implementation is still inhibited by economic priorities.

\section{Scenario C: "Crises Change the World - Going Further with Eco-efficiency"}

Relationships between Western and Eastern regions of the world change for the worse. Trade relations became heavily strained. Combined with crises or conflicts in oil producing countries this led to a new increase in oil price (100-110 USD per barrel) and a significant lower supply of raw materials. As a result, the world economic situation underlies a worldwide economic downturn (GDP growth $<2 \%)$.

The objective to gain more economic independence from countries producing fuel and non-fuel raw materials led to a greater awareness regarding energy consumption and increased the need for improved eco-efficient action. The great influence of media supported this trend. The general public regards aviation as one of the most intensive and extensive raw material consumers and therefore shows decreasing acceptance for this industry. As a result of the pressure generated by the public and the media, regulations are enforced especially concerning fuel consumption and $\mathrm{CO}_{2}$ emissions. As a side effect, the $\mathrm{CO}_{2}$ emission goals were more easily achieved.

Air traffic growth rate decreased because of the tough economic situation. The declining acceptance concerning aviation supported this trend. Due to the decreased growth in air passengers and relatively high oil prices, airline profits are suppressed. Airlines consequently adapt their business models and focus on cost reduction measures. For instance, this is implemented by reducing flight routes and the number of feeder flights resulting in even higher load factors. Airlines focussing on a narrow segment of the market were more exposed to these effects.

Passengers needed to accept higher load factors and limited selection of flights through more flexibility during their journeys. Airlines have to adapt their travel offers by offering somewhat mitigated comfortable alternatives at lower costs. The increased passenger flexibility and awareness for energy efficiency also led to a greater demand for public transportation to airports. Furthermore, alternative means of transportation (e.g. bus, train) are increasingly used instead of short-haul and medium-haul flights.

Air cargo is a vital component for many industries. In order to help carriers reduce their energy consumption, governments support eco-efficiency programs of airlines. Due to economic circumstances, not every country had the possibility to offer extensive economic support to their airlines. As result of the low air traffic demand and a complicated and non-transparent implication process, little liberalisation in ATM has been reached within the last 10 years.

The high oil price increases pressure on aircraft OEMs to improve the eco-efficiency of existing designs, but exerts little pressure to design completely new aircraft. Also, OEMs experience low pressure to increase their production rates due to the disadvantageous financial situations of airlines and relatively low air traffic demand. Retrofits gain importance due to the high pressure on costs and savings.

An increase in awareness for fuel efficiency, pursuit of more independence from fossil energies and the desire to meet strict regulations motivate airlines to increase the use of alternative fuels where economically reasonable. Therein, the limiting factor is the short time frame of new technologies until 2025 and the poor financial situation of most airlines.

\section{Scenario-Specific Criteria Weights}

The general approach of the airline evaluation and the evaluation criteria weights for the status quo (year 2015) are introduced in Table 2 and Table 3 . This section describes the methodology and the derived criteria weights of the scenario-specific airline analysis for the year 2025 .

The first step in applying the evaluation criteria to each specific scenario is to identify the most relevant criteria of the environmental airline analysis area in each scenario. In this foresight project, the four most relevant criteria of each area are identified by analyzing each scenario specifically and consistently with the scenario storyboards.

The second step in which the scenario-specific criteria weights are derived involve identifying the key primary factor with an evaluation weight of at least $50 \%$ as well as three other secondary factors with respective evaluation 
weights with a total accumulation of 50\%. This is to ensure consistency of the various scenarios with the overall scenario methodology as explained in Chapter II.

Table 5 presents the scenario-specific criteria weights as derived from the scenario storyboards. Further qualitative reasoning of the weights can be found in Chapter IV, where the implications for aviation stakeholders are elucidated.

\begin{tabular}{|c|c|c|c|c|}
\hline Area & Criteria & Scenario A & Scenario B & Scenario C \\
\hline \multirow{6}{*}{ 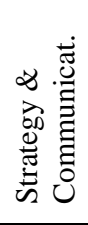 } & Corporate Environmental Targets & $55 \%$ & $30 \%$ & $20 \%$ \\
\hline & Cooperation and Alliances & $15 \%$ & $50 \%$ & $10 \%$ \\
\hline & Communication & $10 \%$ & n.a. & $20 \%$ \\
\hline & Environmental Process & $20 \%$ & n.a. & $50 \%$ \\
\hline & Carbon Offset & n.a. & $10 \%$ & n.a. \\
\hline & Environmental Process & n.a. & $10 \%$ & n.a. \\
\hline \multirow{6}{*}{ 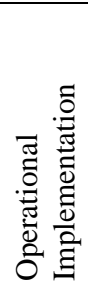 } & Aircraft Fleet & $70 \%$ & $50 \%$ & $50 \%$ \\
\hline & Alternative Fuels & $5 \%$ & n.a. & $15 \%$ \\
\hline & $\begin{array}{l}\text { Flight Operations and ATM } \\
\text { Initiatives }\end{array}$ & $15 \%$ & $30 \%$ & $15 \%$ \\
\hline & Ground Operations and Infrastructure & $10 \%$ & $15 \%$ & n.a. \\
\hline & Maintenance Practices & n.a. & $5 \%$ & n.a. \\
\hline & $\begin{array}{l}\text { In-Flight Waste/Recycling } \\
\text { Management }\end{array}$ & n.a. & n.a. & $20 \%$ \\
\hline
\end{tabular}

Table 5. Scenario-specific criteria weights as used in the airline evaluation

\section{Results: Scenario-specific Implications for Stakeholders}

\section{A. Comparison of the Scenarios}

An overview on major content of the three scenarios is given in Table 6. While Scenario A is driven by a strong growth in air traffic demand of approximately $5 \%$ per annum, Scenario $\mathrm{C}$ is predominated by a tense political environment.

\begin{tabular}{|c|c|c|c|}
\hline & $\begin{array}{l}\text { Scenario A: } \\
\text { Hand in Hand }\end{array}$ & $\begin{array}{l}\text { Scenario B: } \\
\text { Business as Usual? }\end{array}$ & $\begin{array}{l}\text { Scenario C: } \\
\text { Crises Change the World }\end{array}$ \\
\hline $\begin{array}{l}\text { Political } \\
\text { Situation }\end{array}$ & 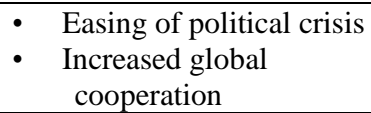 & $\begin{array}{l}\text { Fragmented } \\
\text { international } \\
\text { community }\end{array}$ & $\begin{array}{l}\text { - } \\
\text { - } \\
\text { Middle East-West conflict } \\
\text { conflicts }\end{array}$ \\
\hline $\begin{array}{l}\text { Air Traffic } \\
\text { Demand }\end{array}$ & $\begin{array}{c}\text { Strong growth } \\
(\approx 5 \% \text { p.a. })\end{array}$ & $\begin{array}{l}\text { Moderate growth } \\
(\approx 3 \% \text { p.a. })\end{array}$ & $\begin{array}{l}\text { Decreased growth rate } \\
(<2 \% \text { p.a. })\end{array}$ \\
\hline $\begin{array}{l}\text { Airline Industry } \\
\text { Economic } \\
\text { Situation }\end{array}$ & $\begin{array}{l}\text { Increasing net profits } \\
\text { Emerging markets in } \\
\text { Asia and Middle East } \\
\text { enjoy higher than } \\
\text { average revenues }\end{array}$ & $\begin{array}{l}\text { Moderate, stable net } \\
\text { profits } \\
\text { - }\end{array}$ & - Decreasing net profits \\
\hline $\begin{array}{l}\text { Environmental } \\
\text { Regulations }\end{array}$ & $\begin{array}{l}\text { - Worldwide increasingly } \\
\text { harmonized } \\
\text { regulations } \\
\text { - Focus on reduction of } \\
\text { emissions }\end{array}$ & $\begin{array}{l}\text { Regionally fragmented } \\
\text { increase in regulations }\end{array}$ & $\begin{array}{l}\text { - } \\
\text { - } \quad \text { Focus on energy and } \\
\text { fuel saving }\end{array}$ \\
\hline $\begin{array}{l}\text { Alternative } \\
\text { Fuels }\end{array}$ & $\begin{array}{l}\text { No major economic } \\
\text { importance } \\
\text { - Pilot projects }\end{array}$ & $\begin{array}{l}\text { - } \\
\text { No major economic } \\
\text { importance } \\
\text { - } \quad \text { Pilot projects }\end{array}$ & $\begin{array}{l}\text { - Limited commercial } \\
\text { use } \\
\text { - Intensified research } \\
\text { efforts }\end{array}$ \\
\hline $\begin{array}{l}\text { Influence of } \\
\text { Media }\end{array}$ & $\begin{array}{l}\text { - } \quad \text { Limited influence of } \\
\text { media } \\
\text { - No negative reporting } \\
\text { of aviation } \\
\end{array}$ & $\begin{array}{c}\text { Limited influence of } \\
\text { Media }\end{array}$ & $\begin{array}{l}\text { - Increasing influence of } \\
\text { media } \\
\text { - Negative reporting of } \\
\text { aviation }\end{array}$ \\
\hline
\end{tabular}

Table 6. Overview on major content of the three alternative scenarios

As seen in Table 6, Scenario A with its, in general, economically favorable political situation and being driven by a strong growth in air traffic demand correlates with increasing net profits for the airline industry. Global cooperation 
is at its strongest amongst all scenarios, enabling precise harmonized regulations pertaining the primary goal of emissions reductions.

Scenario B while faced with a largely fragmented international community, paints a situation whereby the airline industry, though faced with pressures to reduce costs and boost revenue, manages to churn out moderate and stable net profits on a whole against the backdrop of fleet and network planning certainty.

Scenario $\mathrm{C}$ with its global political disparity fails to globally harmonize and consolidate the necessary environmental goals as set out by the ICAO General Assembly Resolution A38-18. Despite the fact that air traffic demand is growing at its weakest pace amongst all scenarios, the public perception of failure to improve the environmental sustainability of aviation correlates with a negative media-reporting situation. The role of alternative fuels plays a subordinate role in scenarios A and B. Scenario C slightly differs as the difficult political environment in major oil-exporting regions necessitates energy security in the non-oil-producing regions of the world, hence its limited commercial use.

\section{B. Implications for Aviation Stakeholders}

\section{Implications for Airlines}

The following section discusses implications for airlines derived from the alternative scenarios. Several selected, real airlines were examined and rated according to the airline evaluation as introduced in Chapter II. Three of these airlines are presented in Table 7. Airline 1 represents a South East Asian full-service carrier, Airline 2 stands for a North East Asian full-service carrier, and Airline 3 represents a major American full-service carrier.

\begin{tabular}{|c|c|c|c|}
\hline & Airline $1 \bigcirc$ & Airline $2 \square$ & Airline $3 \triangle$ \\
\hline $\begin{array}{l}\text { Business } \\
\text { Model }\end{array}$ & $\begin{array}{l}\text { - } \quad \text { South East Asian Full } \\
\text { Service Carrier } \\
\text { - } \quad \text { Focus on long haul } \\
\text { Flights }\end{array}$ & $\begin{array}{l}\text { - } \quad \text { North East Asian Full } \\
\text { Service Carrier } \\
\text { - Focus on long haul } \\
\text { Flights }\end{array}$ & $\begin{array}{l}\text { - } \quad \text { Major American Full } \\
\text { Service Carrier } \\
\text { - Heterogeneous short and } \\
\text { long haul fleet }\end{array}$ \\
\hline $\begin{array}{l}\text { Environ- } \\
\text { mental } \\
\text { Strategy }\end{array}$ & $\begin{array}{l}\text { Special focus on route } \\
\text { optimization practices }\end{array}$ & $\begin{array}{l}\text { Target focus on a high } \\
\text { reduction of } \mathrm{CO}_{2} \\
\text { emissions }\end{array}$ & $\begin{array}{l}\text { Strong recycling } \\
\text { program }\end{array}$ \\
\hline $\begin{array}{l}\text { Cooperation } \\
\& \text { Alliances }\end{array}$ & $\begin{array}{l}\text { - Global sustainable fuel } \\
\text { program }\end{array}$ & $\begin{array}{l}\text { - Initiating next- } \\
\text { generation aviation fuel } \\
\text { program } \\
\text { - Strong governmental } \\
\text { cooperation }\end{array}$ & $\begin{array}{l}\text { Focus on strong } \\
\text { governmental an non- } \\
\text { governmental } \\
\text { cooperation }\end{array}$ \\
\hline Fleet Age & $\begin{array}{c}\text { - Average fleet age of } \\
\text { under } 7 \text { years }\end{array}$ & $\begin{array}{l}\text { Average fleet age of } 10 \\
\text { years }\end{array}$ & $\begin{array}{l}\text { - Average fleet age of } 15 \\
\text { years }\end{array}$ \\
\hline
\end{tabular}

Table 7. Characteristics of three airlines analyzed in the airline evaluation

As described in Chapter II, the airline evaluation analyzes each airline for the status quo (year 2015) and within the three scenarios (year 2025) according to the different corresponding criteria weights. Figure 1 displays the evaluation of the three selected airlines according to the criteria listed in Table 2 and Table 3 . The horizontal axis represents the score of "operational implementation", the vertical axis of "strategy and communication". The evaluation of the status quo is given in black, of Scenario A in blue, of Scenario B in green, and of Scenario C in red.

In Scenario A (blue), where all airlines improve their score of "operational implementation" significantly, fleet age is assumed to be of high importance. As a result, Airline 1, having a relatively young fleet, experiences the highest improvements on the horizontal axis.

Scenario C (red) places the airlines in a situation of declining profitability leading to problems with the ability to invest in fleet renewal as there is not enough free cash 'in the system'. Airlines 1 and 2 both move towards a strong focus on implementation and, although all three airlines experience a decrease in their score of "strategy \& communication" due to higher environmental targets, Airline 3 is obliged to continue with a more balanced approach and is the least able to implement operational measures as a consequence of its fleet mix. US network carriers all have very large fleets (in the high hundreds of units) so the rate of introduction of new technology aircraft, or even retrofits, consequently takes a longer amount of time than with the much smaller Asian carriers with which they are compared in this scenario study.

When cross-checking the three scenarios, airlines are met by different requirements regarding their future positioning in the area of "strategy \& communication":

- Scenario A: Focus on setting more challenging corporate environmental targets due to the fact that precise environmental regulations are given. Airlines need to take action in order to fulfill these new standards. 
- Scenario B: Cooperation and alliances with both governmental and non-governmental organizations are gaining more importance to cope with local/regional fragmented regulations. Airline with FSC and LCC in one group need to adapt environmental policies along both business models.

- Scenario C: Environmental processes with strict regulations and standards are core in order to ensure an ecoefficient business model focusing on energy and fuel savings.

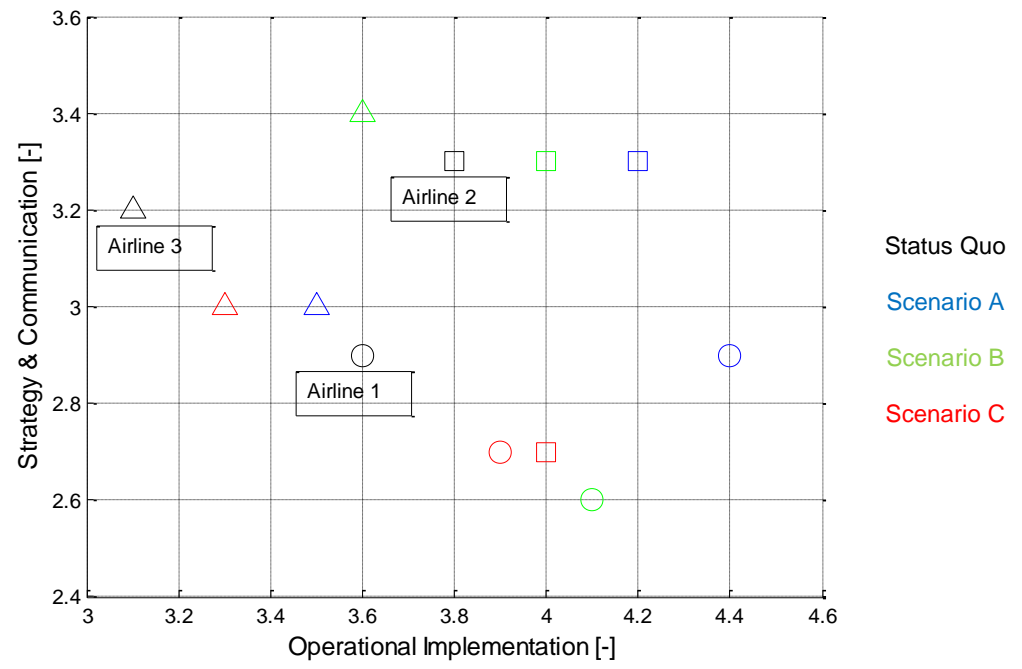

Figure 1. Airline analysis: Scores of three exemplary airlines for status quo (year 2015) and within the three scenarios (year 2025)

Applying a cross-check on the realization of measurements in the field of "operational implementation" will lead to the following implications:

- Aircraft fleet renewals are seen as the most important step towards an improved environmental airline performance in all three scenarios. As mentioned before, in Scenario C it might be difficult for airlines with large fleets to show the necessary investment capabilities.

- Furthermore in-flight and on-ground operational aspects (load factor, optimized routing and airport movements) are of high importance.

- The use of sustainable fuels is not expected to have a significant contribution until 2025, but remain important on the long-term. Hence airlines need engage further in development programs and pilot projects.

To conclude the airline implications, Table 8 sums up possible strategic focuses for airlines within the three alternative scenarios to help meet the scenario-specific environments and resulting requirements. For further explanation and the background of the strategic focuses, see the corresponding scenario storyboards (Chapter III).

\begin{tabular}{|c|c|c|c|}
\hline & $\begin{array}{l}\text { Scenario A: } \\
\text { Hand in Hand }\end{array}$ & $\begin{array}{l}\text { Scenario B: } \\
\text { Business as Usual? }\end{array}$ & $\begin{array}{l}\text { Scenario C: } \\
\text { Crises Change the World }\end{array}$ \\
\hline $\begin{array}{l}\text { Eco-efficiency \& } \\
\text { Sustainability }\end{array}$ & $\begin{array}{l}\text { - } \\
\text { - Impleduction of emissions } \\
\text { guidelines }\end{array}$ & 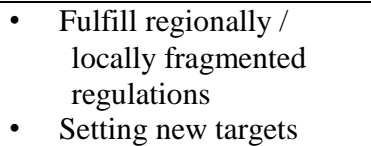 & $\begin{array}{l}\text { - } \quad \text { Reduction of energy and } \\
\text { fuel consumption } \\
\text { - Sufficient environmental } \\
\text { management }\end{array}$ \\
\hline $\begin{array}{l}\text { Cooperation \& } \\
\text { Alliances }\end{array}$ & $\begin{array}{l}\text { Global successful } \\
\text { cooperation }\end{array}$ & $\begin{array}{c}\text { Mainly regional / local } \\
\text { cooperation to adapt to } \\
\text { fragmented regulations }\end{array}$ & $\begin{array}{l}\text { - } \quad \text { Cooperation between } \\
\text { OEMs and airlines to } \\
\text { increase fuel efficiency }\end{array}$ \\
\hline Communication & $\begin{array}{l}\text { - Communication of } \\
\text { environmental strategy } \\
\text { and targets } \\
\text { - Presentation of } \\
\text { achievements }\end{array}$ & $\begin{array}{l}\text { Outlining set } \\
\text { environmental targets }\end{array}$ & $\begin{array}{l}\text { Publication of } \\
\text { environmental } \\
\text { measures } \\
\text { - } \quad \text { Improving image of } \\
\text { airlines and aviation }\end{array}$ \\
\hline
\end{tabular}

Table 8. Scenario-specific implications for airlines: possible strategic focuses 


\section{Implications for Cooperation Between Aircraft OEMs \& Airlines}

According to Chapter II the three alternative scenarios were also considered from an aircraft OEM's point of view. As a result, possible strategic OEM focuses and possible fields of cooperation between the OEM and airlines were gathered as presented in Table 9.

\begin{tabular}{|c|c|c|c|}
\hline & $\begin{array}{l}\text { Scenario A: } \\
\text { Hand in Hand }\end{array}$ & $\begin{array}{l}\text { Scenario B: } \\
\text { Business as Usual? }\end{array}$ & $\begin{array}{l}\text { Scenario C: } \\
\text { Crises Change the World }\end{array}$ \\
\hline $\begin{array}{l}\text { Aircraft } \\
\text { Technology }\end{array}$ & $\begin{array}{lc} & \text { Strong increase of } \\
\text { production rate } \\
\text { Reduction of } \mathrm{CO}_{2} \\
\text { emissions } \\
\end{array}$ & $\begin{array}{l}\text { Flexible cabin } \\
\text { configurations } \\
\text { Increase of production } \\
\text { rate }\end{array}$ & $\begin{array}{ll} & \text { Fuel burn reduction } \\
\text { - } & \text { Short time to market }\end{array}$ \\
\hline $\begin{array}{l}\text { Aircraft } \\
\text { Operations }\end{array}$ & $\begin{array}{l}\text { Improvement of flight } \\
\text { management system } \\
\text { and turn-around times }\end{array}$ & $\begin{array}{l}\text { - Reduction of energy } \\
\text { consumption of ground } \\
\text { operations }\end{array}$ & $\begin{array}{l}\text { - Reduction of energy and } \\
\text { fuel consumption }\end{array}$ \\
\hline ATM Initiatives & $\begin{array}{l}\text { Worldwide harmonized } \\
\text { standard to manage air } \\
\text { traffic demand }\end{array}$ & $\begin{array}{l}\text { Provision of technology } \\
\text { for regionally } \\
\text { diversified use }\end{array}$ & $\begin{array}{l}\text { Cooperation between } \\
\text { OEMs and airlines to } \\
\text { increase fuel efficiency }\end{array}$ \\
\hline $\begin{array}{l}\text { Sustainable } \\
\text { Aviation Fuels }\end{array}$ & $\begin{array}{l}\text { Possibility for strong } \\
\text { reduction of emissions }\end{array}$ & $\begin{array}{l}\text { - Opportunity to increase } \\
\text { efficiency }\end{array}$ & $\begin{array}{l}\text { Opportunity to fulfill } \\
\text { fuel burn targets } \\
\text { - } \quad \text { Saving fossil fuels }\end{array}$ \\
\hline
\end{tabular}

Table 9. Scenario-specific implications for aircraft OEMs: possible strategic focuses and possible fields of cooperation with airlines

Speaking of aircraft technology, Scenario A requires a strong increase in production rates by the OEM as air traffic demand is high and airlines are in a favorable economic situation to invest in their fleets. Higher production rates again may cause capacity problems, also for suppliers of OEMs. Following this, higher production rates will shift the focus on recurring cost in the industrial process. This may require alternative production methods offering the opportunity to rethink the way components are designed and built for the environment. Since $\mathrm{CO}_{2}$ regulations are strict in Scenario A, the OEM should put its main emphasis on the reduction of $\mathrm{CO}_{2}$ emissions of aircraft. On the contrary, Scenario $\mathrm{C}$ requires a maximum in fuel burn reduction by the OEM as airlines are forced to focus on cost reduction. Also, the demand for entirely new aircraft concepts is low in Scenario C, yet retrofits are demanded by the airlines that enable efficiency improvements at relatively low investment costs with short time to market. Generally, and in particular in Scenario B responding to the high regional diversity, a more fragmented segmentation in cabin classes and zones might be needed in order to satisfy customer needs. This may include diverse airline specific needs, more class configuration in one aircraft, and seat configurations that are easy to change within an existing aircraft.

In terms of aircraft operations, Scenario A requires the strongest improvements of flight management systems and reduction of turn-around times in order to meet aviation's capacity problems. These efforts are also favored by globally standardized regulations and procedures. In Scenario $\mathrm{C}$ requirements of aircraft operations are driven by a reduction in energy and fuel consumption. Generally, whereas for short-haul flights the focus may lie on improvements of ground operations, for long-haul flights the potential for improvements is higher within flight operations.

Improvements in air traffic management might play a major role in dealing with a strong growth in air traffic demand, especially in Scenario A. In Scenario B, providing ATM technologies for regionally diversified use could be crucial for OEMs to meet the airlines' needs. In Scenario C, strong cooperation between the OEM and airlines to increase fuel efficiency could be a strategic focus.

Sustainable aviation fuels would play a minor role within all three scenarios in the next ten years. However in the long term, they are of interest in all scenarios, be it primarily for the fulfillment of emission regulations or for the reduction of fuel costs. Thus, research projects on alternative fuels and alternative propulsion systems could be enforced by the OEM. The time to market of new aviation fuel technologies differs between the three scenarios and depends, among other, on the oil price.

\section{Conclusions}

The methodical approach of the scenario study proved to be suitable both for the available time resources and the project team size. However, it is to note that, apart from the scenario approach, the results strongly depend on the knowledge and the motivation of the individual project team members.

During the study, according to a thoroughly defined methodology, three alternative scenarios for the year 2025 have been created specifically focusing on environmental topics in aviation (see Chapter III). By offering a plausible range 
of developments, the scenarios can help stakeholders to define their environmental strategies. Users of the scenarios generally have evaluated the scenarios as consistent.

Also, a simple method has been designed to evaluate an airline's environmental activities (see Chapter II). The method was applied to several real airlines both for assessing their status quo and for estimating the future situation in the three scenarios. In future steps, derived from the scenarios, the robustness of a selected airline's current environmental strategy may be assessed in detail.

Both for airlines and aircraft OEMs possible strategic focuses were determined for each of the three scenarios. Whereas, for instance, Scenario A requires emphasis on a reduction of $\mathrm{CO}_{2}$ emissions in order to fulfill strict emission targets, Scenario C primarily demands a reduction of fuel consumption in order to minimize costs. Resulting strategic focuses for an OEM, for example, are a strong increase in aircraft production rate in Scenario A or the provision of ATM technologies for a regionally highly diversified use in Scenario B. Further implications are discussed in Chapter IV.

Generally speaking, chances for aviation stakeholders, for instance, lie in fleet renewals, especially in the longterm, improved ground and on-flight operations, also short-term, the use of alternative fuels, cooperation with other aviation stakeholders and NGOs, cooperation with governments (e.g. concerning environmental targets), and stronger communication. Risks for stakeholders, for example, lie in the uncertain air traffic demand, the uncertain oil price, strict and/or regionally fragmented environmental regulations (including financial instruments), and a potential decrease in the acceptance of aviation.

\section{References}

${ }^{1}$ Organisation for Economic Co-operation and Development, "Launch of the Transport Outlook 2012," URL: http://www.oecd.org/env/greening-transport/launchofthetransportoutlook2012.htm [cited 29 April 2016].

${ }^{2}$ Air Transportation Action Group, "Beginner's Guide to Aviation Biofuels," 2009.

${ }^{3}$ Air Transportation Action Group, "The right flightpath to reduce aviation emissions: UNFCCC Climate Talks," 2010.

${ }^{4}$ Office for Official Publications of the European Communities, "Meeting society's needs and winning global leadership: European Aeronautics: A vision for 2020," 2001.

5International Air Transport Association, "IATA Technology Roadmap: 4th Edition June 2013," 2013.

${ }^{6}$ van der Heijden, Kees, Scenarios. The Art of Strategic Conversation, $2^{\text {nd }}$ ed., Wiley, Chichester, UK, Hoboken, New Jersey, USA, 2005.

${ }^{7}$ Martelli, A., "Scenario building and scenario planning: state of the art and prospects of evolution," Futures Research Quarterly Summer, 2011.

${ }^{8}$ Bradfield, R., Wright, G., Burt, G., Cairns, G., and van der Heijden, Kees, "The origins and evolution of scenario techniques in long range business planning," Futures, Volume 37, Issue 8, pp. 795-812, 2005.

${ }^{9}$ Börjeson, L., Höjer, M., Dreborg, K.-H., Ekvall, T., and Finnveden, G., "Scenario types and techniques: Towards a user's guide," Futures, Volume 38, Issue 7, 2006, pp. 723-739.

${ }^{10}$ Kuhlmann, A., Phleps, P., and Eelmann, S., An approach for quantification of qualitative scenarios applied to alternative aircraft fuels, Manchester, UK, 26-29 October 2009.

${ }^{11} \mathrm{Phleps}, \mathrm{P}$., and Hornung, M., "Noise and emission targeted economic trade-off for next generation single-aisle aircraft," Journal of Air Transport Management, Vol. 26, 2013, pp. 14-19.

${ }^{12}$ Randt, N. P., Jeßberger, C., Plötner, K., and Becker, A., Air Traffic Growth, Energy and the Environment 2040: Drivers, Challenges and Opportunities for Aviation, Bergamo, IT, 2013.

${ }^{13}$ Gausemeier, J., Fink, A., and Schlake, O., Szenario-Management. Planen und Führen mit Szenarien, Carl Hanser Verlag, München, Wien.

${ }^{14}$ Will, F., Tay, G., and Becker, A., "Green Airlines 2025: Environment and Sustainability in Commercial Aviation," URL:

http://www.lls.mw.tum.de/fileadmin/w00bdw/www/Vorlesungen/TUM_GreenAirlines2025_Handout.pdf [cited 29 April 2016].

${ }^{15}$ Planungsamt der Bundeswehr, "RISK ASSESSMENT AND HORIZON SCANNING," URL: https://www.rahs-bundeswehr.de/ [cited 29 April 2016]. 